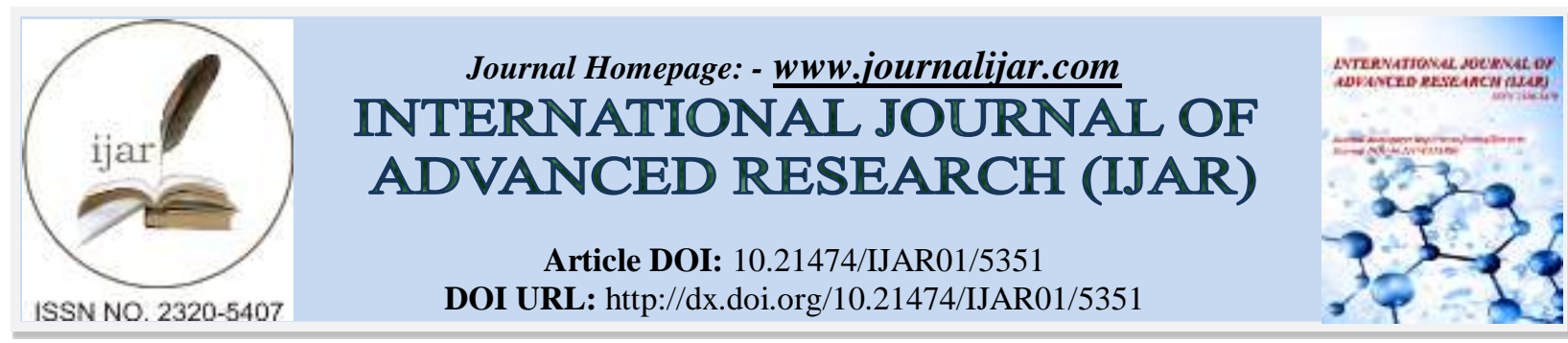

RESEARCH ARTICLE

\title{
FACTORS HAMPERING MASTERY ENGLISH SPEAKING SKILL BY THIRD SEMESTER STUDENTS OF ENGLISH DEPARTMENT OF UNIVERSIDADE DE DILI-TL, IN THE ACADEMIC YEAR 2017”.
}

Paulino Fonseca Guterres.

\section{Manuscript Info}

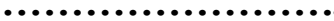

Manuscript History

Received: 07 July 2017

Final Accepted: 09 August 2017

Published: September 2017

\section{Abstract}

Copy Right, IJAR, 2017,. All rights reserved.

\section{Introduction:-}

\section{Background of The Study:-}

Speaking skill An ability in any certain foreign languages is need special intensive treatment of both target learner and the competence potential counterpart procedures. English target learners of third semester, currently at Dili university indicates progressing, however speaking skill still far from its goal. Therefore it needs some emphasizing on techniques and methodologies through formal procedures of teaching learning for minimizing encounter features of target language learners.

The Challenges of the mastery of English speaking skills by the learners as prospective teacher training of English Department of the Universidade de Dili obviously exist. Teaching a language whoever, and the learners whose areas of specific profession in such language have to acquire all segments and competence skill base on its features. Relevant to this idea, the learners have to master English component and skills such as reading, listening as receptive and speaking, writing as productive one.

The assumption of mastering a language is aimed at producing meaningful sounds in its grammar and structures in transferring ideas, views, thought through verbal and written communicative approach. Regarding to the above mentioned, English learners have to dominate all inner aspects when use English as main tool for communication and gaining sciences. English Department's students of teacher training and educational science faculty has the same obligation with those who learn English as second language or be considered living in English community without bilingual languages be applied. Speaking and writing knowledge are very main essential segment in relation to profession on daily bases communications in transferring knowledge, skills for students both verbal and writing process.

The powerless competence of communicative attitudes of third semester students faced some hampering factors that challenging them. As English prospective teachers they ought to power in all skills in the process of academic competences. But realities shows contradicting that English students less use English in their daily communication with class mate, lecturers at campus even in class tended to speak Tetum was prevailing. 
The writer wanted to know what are on-going aspects that impede students' mastery of English speaking skill far from the teaching learning objectives as the invisible circumstances which was not fully understand and without anticipation acts of improving, executing, assessment by the university's key stakeholders. Dili university has stands over a decade but there were no adequate facilities for English department program students to develop their English skills components. The not preoccupied by the specific structural leaders of the university could be considered as the contributor of the less development students' competences in certain specific skills. Meanwhile, the enthusiastic youths towards learning English indicated increasing as sword sling shots up. The breaches phenomenology features were inexpressible by the learners or the hindering issues without any claims. Unawareness learners keep hushed and identify of some factors challenging English learners were going to reach their expectation of leaning English as foreign language in Timor Leste and the be their future proper profession that would not avoidable.

Explain more details.

Looked into the English students' research real situation shown that less used English, it was also impacted chance and drove researcher would like to look into deeply then wanted to describe whatever found on ground and eager to set alternative for a contributively solution purposes. From the preliminary observation stood up of the learners interaction among students and students with lectures outside of the class in campus on daily feature bases the English learners shouting, healing, demanding, offering and others academics' activities relaying on Tetum.

Other occasions contributed like utilization increasing number of students from time to time it has more possibility opportunity to practice their English with their community as a large society in campus. Any type of conversation must be taught and expressed in English features circumstance but did not find possibility signs. The philosophy and sociology perspective of become English teachers in a high expectation of every learner.

Due to a Timor Leste's linguistics features of different grammar, pronunciation and tenses. As the bases, Timor Leste adopted Portuguese along with Tetum as official languages in which both them have different grammar as well. Consequently, most of Timorese young people are confused to which properly language. Due to Tetum development, majority vocabularies are taken from Portuguese language, English even Bahasa or local languages. Due to multi-lingual used at sometimes Timorese mixed up daily communication of words, phrases from Tetum, Bahasa and Portuguese.

The most confusion was the English words and phrases pronunciation of similar spelling be expressed with different pronounced, different spelling but same pronunciations belongs to a differ sociolinguistics.

The utterances literal prescription in English teaching materials as the knowledge frame works using by its learners into real practice for transferring messages in both verbal discourse and text discourses of interlocutors elsewhere they are. But the reality that students shown in the campus of Unversidade de Dili, Timor Leste, did not indicate as English learners, especially English Department students as prospective and professions teachers inside-outside classroom, at relevant activities were being shown not supported. Even upper semester students mostly delivered their massages majority Tetum and natives so far. The discrepancy between expectations and realities was far from learners' facilitators' and profession department's objectives as whole integrated components in an education institution.

In a communicative approach a speaker asked someone else his/ her interlocutor to act out as part of philosophy purposes. The communicator however, has several utterances to choose in delivering message depending on the effect that she/he wanted it to happen on his/ her interlocutor but it did not find in the students' interaction of daily communication.

From the above mentioned perspectives the writer wanted to identify two main factors of learning and mastery English for an English prospective profession and describe them in speaking skill correspondence through linguistics features: grammar, pronunciation; and sociology features: when and how the language was used in the community (English-students) faced by learners as the main challenge.

The writer would like to use the data findings for developing students' speaking skills through providing direct support facilities. Cooperate with chief of English education program to find some appropriate alternative solutions for better preparation, in order preventing inhabitation effective learning students, design teaching materials, 
delivering teaching methodology and etc. This type of research yet taken and discussed by the stake holders of the institution level to prevent and support un-effective students in carrying out their proper science to reach institution and students objectives.

\section{Statement of The Problem:-}

What are the main internal and external factors that hampering third semester students' mastery English speaking skill to be discussed as concerns in the following statements:

1. What are internal factors which influence students' ability in speaking skill while studying English as profession substance of the teacher training and educational science faculty at Universidade de Dili?

2. What are the external factors influence third semester students' mastery English speaking skills in his/her daily communication at campus?

Due to language variation of the world as a one factor that contribute challenges in learning foreign language, include world franca of English itself.

a. Grammatical features

Languages differ in grammatical and pronunciation features occurs. Such as some languages have simple features in certain area of the languages. The target language grammatical features may be complex to another language when transfer target language formula into native learners' wouldl be contradictive. English has its own specific different pronunciation on word syllable stress, similar and different pronunciations of a similar spelling, different of vowel and consonant letters and etc.

\section{b. Sociology Features}

The theoretically circumstances of social influences on learners of learning English and using it in their daily communication must be getting development during their on- going learning with the English Department students' community. The Significant progress of learning English as target language is also assume social's contribution especially from professional lectures and institution as the direct core responsible of preparing conditions where the institution is settled. The English department students can be considered a potential social where can develop its students' speaking abilities in a short period of time. However, the English learners did not prove any significant progress result in their rapidly communication.

The speaking skill would get improvement if learners have to use the external and internal factors with effectively and continuum when they are in their English community or practicing personally speaking in mind. From the philosophy and psychology aspects of learning must be focused as main segment that link with inner factors of enthusiastic, belonging the profession. Enable them in English components grammar, structure and vocabulary then associated with English competence of reading, writing speaking and listening.

\section{The Objective of The study.}

The objective of this study was attempt to answer the two questions provided above mentioned as the contributed problems for this phenomenal scientific study at Universidade de Dili.

1. To describe third students' English speaking skill correspondences which were challenging them from internal and external factors language competence and component.

2. To find and describe speaking skill in English correspondence which was challenging internal factors viewed from language and sociology features. After researcher would conclude the research and wanted to describe the fact data in totally represent for any further research objection.

\section{The Significance of the Study:-}

This significant of the study would be lay out in the two phases as figured out in the following three note worthies, they were:

\section{Theoretical}

This study was significant for the reason that it was going to describe about students' encountered internal and external influence factors inmastering English speaking competence and performance while they are studying at Universidade de Dili and then find minimum appropriate solution. 
2. This research's data also would help the English lecturers in designing teaching speaking materials, and provide learning speaking skill in English classroom accordance with social economy development that tied with informatics technology utilization awareness and preparing conditions which support students' English speaking skills and the un-neglected culture awareness up to date as the minimum solution for the overcomes hampering factors. The research data would be used as development tool in setting up rules and regulations of the English Department in try out alternative solution.

3. The first research's data would be a starting teaching learning English action research at Dili University and for its future development. To open for next coming classroom action research in or to develop designing teaching materials, methods of teaching, applying new appropriate approaches more benefit to subjects objectives and out puts.

2. Practical

a. The data would be used for the development competences of lectures, students, institution stakeholders in developing policies to contribute intellectual capability for the further development to reach the general and specific objectives more focuses on researching the area of education under such university.

b. Minimizing students' external factors regarding facilities of the university, campus environment and internal factors of lack vocabulary knowledgeable, grammar, be shy of being laughed and local linguistic features and etc., by providing facilities, advocating, creating speaking atmospheres and supportive activities.

c. Designing and modifying institution curriculum and delivering speaking material for more practical emphasize and students' centralize.

\section{The Scope and Limitation:-}

The scope of this study was on internal and external factors hampering students' mastery English speaking skill among students' and other's correspondence for the third semester of English Department of Universidade de Dili, Timor Leste in academic year 2017.

The limitation data source of the research would centralised to third semester class A due to a such class would different the other classes. This rese research would find out what were the challenges the class.

The reason purpose for choosing of this proposal title was a requirement of the study program to find some alternatives solution trough a research.

The English linguistics features is not easy to learn and master third semester students of UNDL in compare with Tetum and Bahasa.

English is adopted by the government as working language along with Bahasa Indonesia and on the other hand English will the professional skill to be used after the third semester students concluding their study at UNDIL. The writer expecting that teaching learning English was not student's outcomes but be relay on output would be more essential.

\section{The Definition of Terms:-}

In this section, the writer would like to present some definitions of terms with the as the part of the proposal title when it approved by the supervisor easily and get a clear meaning of the title of this thesis proposal. The terms defined here are in the linguistic terms as follow:

1. A describe, means is the process of explaining or evocative a certain item with a prescription.

2. Study, it means that an activity in deep investigation to find a result or fact.

3. Other word of observing with careful or more pay attention, another word means search/ research.

4. Factors, means something which are hindering or hampering as challenge or make more difficult to go through.

5. Hampering, a challenging and influence of any subject activities are on going.

6. Third semester means a period of time of 18 months in an academic process of learning, or six months coding times three.

7. Students, people who studying science at school or university.

8. Mastery English, the ability of a subject comprehension, understanding towards English component and skills with brain process then use it for communication in both speaking and writing.

9. Speaking skill, having power of understand competence by brain. 
10. English Department of Universidade de Dili-TL, one of English language profession learning institution under Dili University in Timor Leste, Asian country in east south of Asia that locates land borderline with Indonesia and Timor sea border with Australia.

11. Academic year 2017, means of a specific period of formal procedures teaching learning participation training or studying skill time within a century.

\section{The Organization of the Writing:-}

In the organization of the thesis writing here is showing the process or systematic of writing whole proposal. This thesis writing, it comprises of four chapters:

Chapter I introduction that comprises of background of the study, the statement of the problems, the objectives of the study, the significance of the study, the scope and limitation, the definition of terms and the organization of the thesis writing.

Chapter II is contains review of related literature that consists of the concepts of words which used as the process of exploring of this thesis writing itself. The concepts and the most words used in this thesis writing are explored.

Chapter III is entails methodology of research that consists of research design, procedure of data collection, subject of the study, instrument, method used, the technique of data describing, technique of data presentation and time line for such research.

Chapter IV is comprises of research findings and discussions that presenting the what are internal and external factors that hindering students in the mastery in English speaking skills.

Chapter $\mathrm{V}$ is encompasses conclusions and suggestions, showing the findings of the research and alternative inputs for the English department students and relevant institutions' leaders who are responsible for the academics development. In this chapter is more focus on factors that hindering students' capabilities in learning English as foreign language in Timor Leste. The most internal and external factors is contributed by the development in the one decade independence country.

\section{Chapter ii \\ Review of related literature:-}

In this chapter the writer descries a little bit about the concept of mastery English speaking skill and language component (grammar, Vocabulary and pronunciation) and effective learning in mastery English to improve speaking skill for the third students of English Department of Universidade the Dili-TL, in academic year 2017.

\section{Language Function:-}

Target of use English language of the people the state of Republic Democratica de Timor Leste (RDTL).

The Constitution of the Republic article 159 states about the working languages in Timor Leste. In this article English and Bahasa Indonesia as working languages along with official languages of Tetum and Portuguese which are using at public administration when necessary. The both working languages also adopt by the Ministry of Education as compulsory subject to be taught at secondary public schools. The more priority English has being taught as compulsory subject at pre-secondary schools.

Other chance, English more possibility taking place at the superior level of education due to every university or academic institution has its English education study program. Beside of this, Ministry of Education and government allocating huge state budgets for higher capacity building scholarships in English at abroad.

The above of target English use in Timor Leste as the foundation of English curriculum that has to facilitate English teachers' and lectures' in their planning program going to apply. The essential role of teachers in a successive teaching English for students' speaking competence skill automatically relay on teachers' competence and students' characteristics, attitudes and influence factors. An English teacher's major role play in learning will become essential factors to determine students' successes. Some supportive foundation in line with teachers' procedures in facilitating students' abilities are the adequate relevant book sources and curriculum. Without a teacher profession 
and inner competence as equipped by God and His intervention there will be not process and the profession. Any skills of such competence are produced by a skilful source competence.

\section{Concept of Speaking Skill:-}

Concept of speaking skill or used to mention in term naturally, speaking is described as the meaningful sounds production of human organs speech within an intention to produce differential verbal or unwritten answers and responses to interlocutors and listeners. A speaking skill is considered a concept of (Bygate, 1987: 5-6). States that, traditionally speaking is defined as the production of auditory signals designed to produce differential verbal responses in a listener. This sense just focuses of perceptive skill. Speaking is also considered as combining sounds in a systematic way meaningful according to certain language features utterances.

Defining of speaking is inner proficiencies of interaction component skills that involve making some sets of decision regards to communication properly process. Adopting Bygate view by Florez (1999:2) and Howarth (2001:39-44) they define that speaking as a two way process that involving a real communication of ideas, information or feelings. The ideas can be considered that speaking is the primary prominent for the physical text.

The effort to elaborate more in interactive nature in the prominent speaking "Burns \& Joyce (1997:7) and Louma (2004:2) defined speaking as interactive process of instructing meaning that involves producing, receiving and processing information. Speaking relay on form and meaning are depend on the context in which it occurs, including the participants themselves, the physical environment and the purposes for speaking.

Speaking is presence often with spontaneously, start and ending contextual, and evolving, but not always unpredictable (Florez 1996:2). The idea is tends to recur in certain discourse situation in a real life and tends unpredictable. Example, two old friend English learners when suddenly met in an unpredicted time and place then engaged in speaking about where have being, jobs, family, hot issues, expressing past event and so on. The open-end speaking; when two or three talking are about unknown and new things seriously.

\section{Internal factors:-}

The fundamental aspects of speaking skills are relay on vocabulary knowledge stock, grammar, structure, pronunciation and four language competence skills, reading, writing, speaking and listening.

In regards to the research title, the hampering internal factors of English speaking skill will be focus on below skills as dependent aspects. According to Kolo, (2008:2) the idealism problems in speaking skills as follows:

a. In habitation: worried about making mistakes, fearful of criticism, or losing face, or simply shy of the attention that their speech attracts;

b. Nothing to shy: they cannot think of everything to say they have no motives, to express themselves beyond the guilty feeling that they should be speaking;

c. Low or uneven participation: there is a tendency of some learners to dominate; others speakers are very little or not at all;

d. Mother tongue use: if they are practice speaking in small groups; it can be quite difficult to get some studentsparticularly the less disciplined or motivated ones to keep talking in the target language (Brown, 1994).

Every student has his or her own difficulties in learning English. As experienced that, when writer taught English for economics' classes the students worried in making mistake when spoke English. Some of the students wanted to answer addressed questions or gave comment would be in Tetum or Bahasa. The students as learners they have their own difficulties or problems in learning target language. The other tried out was that a target learner has to ignore his her language feature and effective learning from sources available.

It has been described before in the background of study, there are four skills; such as reading and listening as receptive skill, then speaking and writing as productive skills. These four skills are close related to one another. Speaking skill is a prominent for oral communication for the basic reason in English for a primarily spoken. In relation to this regard, widow son (in Makoni, 201) states that speaking skill is the active and productive skill of a language. While Brown defines speaking skill as a skill in producing oral language. The implementation of such a skill can be seen. Example, when two or four people interact aimed at maintaining social relationship among them. 
In case of teaching speaking skill, according to Leo (in Basan, 2009:2) there asre several strategies that can be use. The first is that the teacher should be creative in the sense that not applies monotonous method and technique. It may be started by doing some elicitation, brain storming, telling experiences, stores, anecdotes, asking a quiz, doing a small game, singing, joking and as being prominent so forth. The second is that says that when the teacher tells something, he or she should make sure that students as leaners listen to him or her. The third is that the teacher should create a relaxing atmosphere and encourage the students to speak. The next is that the teacher should act not only as a facilitator but as partnerin pair work or a member of group discussion.

The last is that the teacher is recommended to use correct teaching aids to build the students' willingness in speaking. According to Brown, as quoted by Makoni (2011:8), some principle that should be considered in teaching speaking skill, in teaching English speaking skill is no exception as follows:

1. Focus on both fluency and accuracy.

2. Provide intrinsic motivation technique,

3. Encourage the use of authentic language in meaningful contexts,

4. Provide appropriate feedback and correction,

5. Capitalized on the natural link between speaking and listening,

6. Give students opportunity to initiate and oral communication,

7. Encourage the development of speaking strategies.

8. Particularly in improving speaking skill is not easy for students.

\section{External Factors:-}

The second factors influencing third semester students' in mastery English speaking skills are whatever circumstances of social environment out site the learners power that cannot impeding by a member or small group in a certain community. In this research the writer just mentioning the social background where the target learners are accommodating, support facilities, social common interaction, never being with target native speakers. Most influencing causative were financial support in providing English books, without target plan. Within the family not being using English but local language use was dominating. Other factors view from institution source facilities, curriculum, liberalism or democracy interference in education institution and etc.

\section{The Concept of Grammar:-}

Grammar plays an important role in the language because contains the rulers to be followed. When people discuss the grammar, they should be sure with what they know about words means. Grammar is usually taken to mean "correctness in speaking and writing".

Grammar on the other hand refers to the structure of language. When people talk about the grammar of language, they are not talking about preferred choices among words and phrases but the system of a language; the way people combine the words to produce the meaning. William, (1982: 485) states that grammar as the grammar as the abstract system of rules in term of which a person's master of his native language can be explained.

Fromkin, Blairand Collins in an introduction to language (2000:10), defines that the sound and sound patterns, the basic units of meaning, such as words and the rules to combine them to constitute a grammar and a language. Grammar is known as a system of a language which contains the abstract rules that regulates the language users. The language users should be followed the rules as well as possible in order to guarantee the accuracy. Grammar Translation Method teaching speaking a actually, grammar translation method is a well-known method used for teaching grammar. According to Richard and Rogers (1985), "The Grammar Translation Method in fact firstly known in the United States as the Prussian method, which entitled the Ciceronian or the Prussian method of teaching the element of the language," (p. 53). Grammar Translation Method is a way of studying a language that approaches the language firstly through detail analysis of its grammar rules. This is followed by an application of know ledge of the task of translation sentences and test to the target language as they are seen in the following steps of the classroom activity.

The main activity in the classroom where the grammar translation method used is "translation" the medium instruction like the language use to explain grammar meaning of vocabulary items and cultural aspect in the native language of the students of first language (L1). The use of grammar is translation; is a mean of medium instruction for second language learners. 
According to Mary Spratt, Alan Pulverness and Melanie Williams: "Tasks and less controlled practice activities give more opportunity than controlled activities for learners to practice, communicate, interaction and fluency" 1 . One of the major benefits of this approach is that it is learner-centred. Unlike other traditional approaches, here the learner performs the task and takes an active part while the teacher happens to be a guide, mentor and facilitator and correct the mistakes when needed, thereby remaining passive. This approach, when used in teaching speaking skills enables in minimizing teacher talk time and maximizing learner talk time, resulting in the progress in learners speaking skills.

As said by Sarah Philpot: "Learners learn better when they are engaged, relaxed and having fun" 2.The task based approach makes the learners engaged, relaxed and as they get involved into the task/activity, they derive fun out of it. Thus the entire learning process becomes enjoyable and efficient.

These are a few problems and remedies of learning English language as a second/foreign language.

There are many more factors pertaining to phonological, grammatical and other linguistic aspects which create a lot of problems in the process of language acquisition. Following a proper teaching strategy in the class would resolve many problems.

According to Jon Taylor: "Learning necessarily takes place through trial and error:: students need therefore, plenty of opportunity for such trial"3. Speaking is one of the central elements of communication. Effective instruction derived from the careful analysis of this area, efficient language input and speech -promotion activities, which will enable chances to speak English fluently and appropriately. Teaching English as a second/foreign language can be fun if it is done in the right way. According to peter Watkins "Teachers need to provide a variety of speaking activities to reflect the variety of speaking activities learners would engage in a real life.

\section{Chapter iii \\ Methodology of research:- \\ Research Approach/Descriptive Qualitative:-}

This study is a qualitative research where the writer intending to describe the factors hampering mastering English speak skill in their own English community while at campus practicing him or her-self act likely crazy's speaking. The writer is going to start with data pick up in the field by distribute topics for each data source to present English speaking skill in the class to observe for identify the data sources' internal factors on language component skills and language competence. The second activity, after gathering data needed of the first step, then carrying out interviewing students' validating data.

The needs to follow some steps as follow; research approach, research role, procedure of data collection, source of the study, instrument of the study, method use in the study, technique use for describing the data, technique used for presenting the data and time used for carrying out the research;

\section{Role of researcher:-}

Role of researcher in this study would be a main instrument for controlling whole aspects of the research studies. The researcher himself going to gathering information from data source of third semester students without a representative person. The personal observation was directly in the classroom under cooperating with speaking subject lecture.

\section{Setting of Research:-}

The research location in this study was carried out at the third semester students of English Department "Teacher Training and Educational Science Faculty" of Universidade de Dili. This research would select purposive enthusiasm and accordance with chance of participating English speaking practice an open performance.

\subsubsection{Library Observation, The library observation was done get second support} references

3.3.2. Site Research was conducted at English Study program and under coordination with Universidade Dili's stake holders. The research implemented had cooperation with English speaking lecture for settled the field research in order to get primary data of this study. 


\section{Data Sources:-}

The data sources of this research were the third semesters students of English department specially class A. The selection of class and sources would determine by researcher as main instrument to avoid any interferences. The interferences were those students who are being working outside the country and tourist guiders.

\section{Procedure of Data Collection:-}

Before conduct a field research at English Department of Teacher Training and Educational Science Faculty under Dili University in Timor Leste. As a legal process needs some requisites to fulfill academic specific purpose, the writer needs to go through some procedures as follows:

a. The writer was got a permission research letter of recommendation from the Academic Administration of ParscaSarjana Nusa Cendana University.

b. The writer then obtain permission from English educational faculty and the English speaking subject supervisor then conducted the research, under cooperation with relevant component of the such institution.

c. Provided reading text, observation sheet, a guide questionnaire and oral interview.

d. After obtaining permission, the writer have a good cooperated with speaking course material supervisor of English Department and third semester students of class A for gathering primary data at field.

\section{Research Instrument:-}

The writer was would like to use non-human and human resources.

3.6.1 Human; the writer, third semester students, Lecturer of the English speaking

class.

3.6.2 Non-Human; flash recorder, webcam, manuscript, etc.

3.6.3 Open text interview and oral interview to get the real factors that not touch

3.6.4 Speaking skill evaluation through text.

\section{Field Research:-}

In conducting field research, the writer used two steps for elaborating description this study. These steps were: first step was provided topics in English text for each source/group which relevant to the level of the students then they were given with a text of 10 to 15 allowed read text presented by arguing in English speaking skills performance during data gathering in class or an appropriate venue. In this process, writer provided same criteria for control scoring or evaluate. Second, oral interview for a cross check conformation on internal and external factors that uncover in text interview or speaking skill performances.

\section{Technique of Data Presenting:-}

After the data had been in hand, the writer presents them by naturalistic description to present whatever the data obtained. The writer just described the data findings of internal and external factors as factors hampering third semester students in mastery English speaking skill.

\section{Time Line:-}

After the proposal accepted follow first and second supervisors agreement, under guided of both supervisors, writer presented seminar on research proposal and approved by board of examiners and the timeline allocation as seen in the below table.

Time line of English Education Program

Academic year 2017

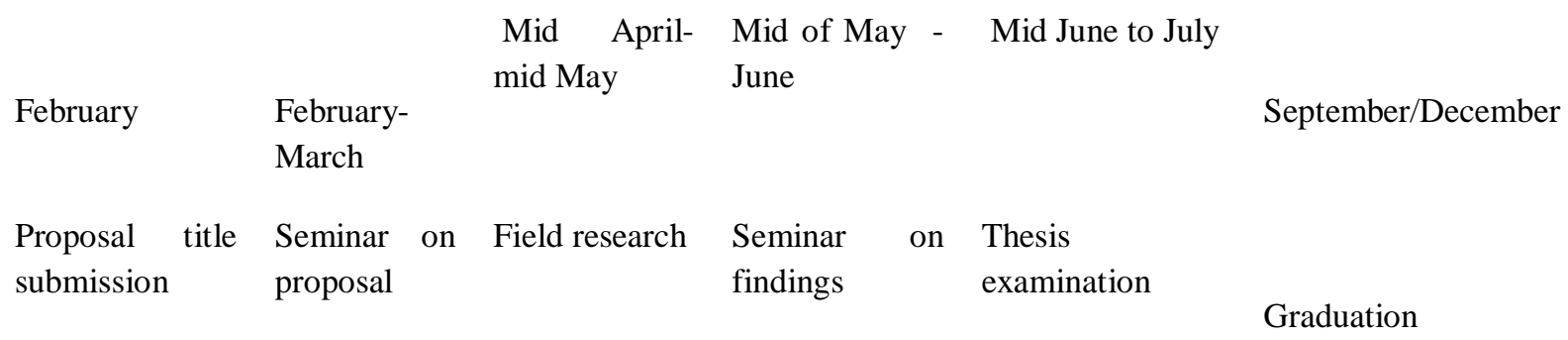




\section{Chapter iv \\ Findings and discussions:-}

In the this chapter the writer presents the two factors that hampering the mastery of English speaking skill by third semester students of English Study program of Universidade the Dili- Timor Leste. To support research title that there was lack of English speaking skill did by third semester students of the English Department in the academic year of 2017.

Then writer tried to implement in providing short text for the source candidates of class A through a text reading of between five to-15 lines in $30-45$ minutes time. Then each participant represented in front of the other participants and observer for the purpose of shared what was the content text talking about and let them to develop with their own ideas in presenting speaking skill performance. The charger time per presenter was five to fifteen minutes; all the presenters should need 360 minutes to conclude their presentation. But the reality shown differently, the students just needed two hours and forty five minutes concluded their presentation.

An interviewed with English speaking teacher Mr. Marcelino Caldas stated that the third semester students got less orientations and guides in developing speaking abilities. The less guide and orientations were caused by the lack of methodology teaching speaking skill books and other unsatisfied facilities supports.

Some students had less concentration in learning English as target for their future jobs chance but just memorized lesson learnt therefore when they asked to explore for speaking performance at finally they do nothing.

This technique was used to discover the ability developing of speaking skills, mental performance condition level of dominate a 15 lines text, how fluency speaking skill after reading a text towards the factors that impeding speaking abilities of the third semester students of English department as the future candidates of teaching English as foreign language and also as the working language along with Bahasa Indonesia in Timor Leste.

From the observation, writer used chance conducted collect data through answer questionnaires. For accuracy data the researcher also direct interview the sources with a guide questions in order to confirm the internal and external factors that hindering them in mastering English speaking skills. It was found that there are internal and external factors influenced the third semester students in mastery English speaking skill.

\section{Findings of Internal and external factors:- \\ Internal factors:-}

The internal factor which were hindering speaking skill of third semester students

Class A of English Department study program of Universidade de Dili-Tl, in academic year 2017. The linguistic features as mentioned above such as lack of vocabulary, wrong pronunciation, grammar and spelling and the psychology aspects that directly affect in learning process.

\section{Linguistics Features}

The first linguistics factor hampering third semester students in mastery English speaking skill in the internal factor found of the research through language features such as:

4.1.1. Lack Knowledge of Vocabularies

Lack of vocabularies of English mostly direct impact towards on students in free

speaking skill in presenting related ideas of short English text. This argument was expressed by 18 data sources out of 24 informants. The other 6 of quick learners were said that the content of an English text sometimes made difficulties to develop ideas to share with others that connected to certain phrases and sentences of a written text.

4.1.2. Wrong pronunciation, grammar and spelling

Wrong pronunciation of English words and phrases were done by the 20 data sources. The pronunciation was influenced by the learners' habit of Tetum, Portuguese and Bahasa alphabetical pronunciations.

\section{The Psychology Aspect:-}

The psychology aspects found of this research covered of leaners' mentalities as stated in the following points.

\subsubsection{Shy to speak}


The 21 out of 24 students of the data sources confirmed that they shy to express their ideas through English speaking skill due to their English vocabs, grammar and pronunciation still far from the its sufficient target.

\subsubsection{Get difficult in remembering lesson learnt or memorize}

During in an interactive interviewed fourteen students confirmed that they could not completely know all lesson learnt and implement into practice. It also caused by the minimum used of time to learn and comprehend English arbitrary construction combination of wards towards contextual of a comparable and different meaning.

\subsubsection{Less enthusiasm in learning,}

Low spirit in learning English of the third semester students of class A were informed that because they did not have enough books English language teaching and times to do their tasks. There was without chance in a week to finalise tasks due to limited to teaching process. English speaking teacher has to manage extra time or deducted class meeting chance for finalise tasks.

\subsubsection{Less selves' confidence in poor verbal communication.}

The twelve (12) students stated that there were less confidence to speak English among students and they could not build working groups as a strategy for communication. There were no serious verbal communication take place while and after class meeting, even an English lecture who most share time with students dominantly communicated in Tetum.

\subsubsection{Inhabitant of learning English}

Six students out of 24 were share in a direct interview stated that inhabitant learning foreign language through reading was the powerfull factor to dominate English vocab and grammar into speaking practice.

\subsubsection{The Non-linguistics Factors}

The second challenge external Factors which hampering third semester students in mastery English speaking skill such as:

Lack of Facilities, books, Students' Centre,

All data source of 24 informed that faculty of education and the Dili university lack supportive facilities as above mentioned.

Social factors, at home and campus

The third semester of English department program as the informants of this research presented that they just read the English hand outs lessons given by the lectures but no communication exist at home and with other colleagues in a same community. Because were noEnglish leraners arround as parttners to share ideas in English.

Data sources of 8 out of 24 students stated that at campus they rarely communicating in English among them. To explain duties and tasks' consultation in Tetum and fined words, phrases, sentences meaning support searched was through Bahasa Indonesia.

Factor of Economy,

The 22 students of the third semester all stated that their families' economic background are rural peasents with weak incomes that could not fullfill their demand. There were only two students informed that their parents are public civil servants.

Lack of Properly of Guide, Cultural Aspect

The 16 students stated about less properly guide in the way of communication, advices special expert of English skill performance. The students weak to consult and shared their challenged problem with permanent lecturers due to the lecturers they had own occupied tasks.

Dominant Use of Mother-Tongue and Tetum

The students also regretted that they more used of Tetum to communicated with

other students and even with English lecturers in class outside the class at campus. There no more chance at all when backed home totally used mother tongue. These two conditions were contributed fossilized speech organs in learning English for better utterances English words. 
4.1.2.6. Poor Building Confidence

The students have no groups for debates any topic inside the class or out of the class.

\section{Discussions:-}

\subsubsection{Findings of Internal Factors}

Data sources discovered internal factors that hindering speaking skill are as follows:

\subsubsection{The Linguistics Features on this research study}

The first linguistics features factor influence third semester students class A of English department study program in mastery English speaking skill of the study such as:

\subsection{Lack Knowledge on Vocabularies.}

The data shows that out of 24 informants there were 18 data sources stated that lack vocabularies are direct affectation on their English speaking skill practice with friends both in class and at campus. The additional aspect of the first internal factor which unavoidable was the lack motivation in learning English. Lower motivation levels or lack of motivation was a variable or caused reason in hindering the third semester students from active participation in speaking activities to develop speaking skills. It leaded to reluctance in active participation in the speaking activities leading to poor practice or no practice at all by transfer personal and other experienced topics for as basic change. The third one was when the third semester students learn English vocabulary and its contextual meaning they have to search both meaning through Bahasa even their skill of such language also very limited. From the text of 15 lines out of 24 there were 18 students could not make any significant restatement to develop their speaking skill of the text shared.

\subsection{Miss-understand Contextual meaning}

Due to low motivation in studying English mostly direct impact to miss comprehension towards any short dialogue written text then got difficult into speaking practice. The other aspects were spoken language context and less experience of the students in the learning process.

\subsection{Wrong Pronunciation, Grammar and Spelling}

English pronunciations are very unique which differ from Tetum, Bahasa Indonesia and Portuguese or the way how to read local or national language text. Out of the 24 data sources 12 students were pronounced some words and phrases as well as Tetum and Portuguese texts. The mispronunciation mostly relay on new word or synonym words in a written text. The students also mispronounced of wards, such as less be pronounced (lis) last become less, turn become "tun", interrupt "interruup' lift "liv" and speak English " espik inglis or anglis", want "wont", Lift "liv", Turn "tun", consider "considere", school " escuul” so on.

Attributable to mispronunciation, lack of vocabulary knowledge some students would not speak up and give comments then terminated their presence in front of the other participants.

The mispronunciation caused of inhabit most use the such words, did not the words' pronunciation with English standard dictionaries and English laboratory.

\section{a. Structure or grammar}

In the organization of the students' writing ways were mostly influenced by the Tetum and mother tongues' structures. Due to they were used thought in Tetum or mother tongue then arranged English into that formula. The organization of students writing can be seen in appendix...

\section{b. Spelling}

The way of composing ideas some students still influenced with local language features structure and the ways of writing still far from their expectation. Example of the student's writing "When I apply to study English at Faculdade Ciencia da Educação of UNDIL, I expect that I want to be a good English Teacher in the future. The way they wrote wanted (wont), experience (expressing) find (fine) important (importent). The correct one was "when I applied for study English Study program at FCE Universidade de Dili, I expected to become a good English teacher.

The spelling of English writing done by some of third semester students wrote a word based on as in local system as stated in the above mentioned. 
The students wrote some English words asthe wordspronounced according English alphabets, appendix ....

\subsubsection{The Psychology Aspect}

\subsubsection{Shy}

Shy is one of the learners' uncomfortable feelings of internal factors which can get the stimulus of student's language less development in arguing certain ideas to speak English in front of more audiences of being making mistakes that would create criticize by the listeners. Shy is an uncomfortable feeling that can be seen from students face when they would speak in English about any conditions those they did not really aware or mastery to present in different paraphrases of the same contents those would embarrassing due to a minimum knowledge of English components and skills.

Regarding to inappropriate feelings causing students speak repeatedly certain words before find connection ideas in their presentations.

The grammatical rules between English and Tetum or vernacular are quite different.

In the research observation on English speaking skills through a reading English text and presenting by each data sources indicated that all of the third semesters students of class A they were facing different level of internal factors such weak at remembering, how to apply lesson learnt in a real situation.

\subsubsection{The Language Usage Influence}

Mother-tongue, Tetum, Bahasa Portuguese pattern and its influence Timorese students' ways of used certain utterance have to relay on a particular set of pattern of pronunciation, intonation, stress-pattern and phonology of their mother-tongue, Tetum, Bahasa, Portuguese in which each language has an obvious impact on acquiring English foreign language. Due to the students' habits of learning a foreign language normally viewing through mother tongue's pattern then formulating English words, phrases and sentence based on the local language in the interfering meaning into English. Therefore, the frame of English when after elaborating ideas from mother tongue or national language be always out of the nature structures.

\subsubsection{Mother Tongue and Tetum}

Third semester students were generally tended made dominant use of their mother-tongue and Tetum when have chance enter to the activities in productive skill of speaking. When the third semester students of class A were asked to perform a speaking practice they first chance immediately commence formulate about the text/topic in their mother tongue or Tetum, Bahasa, frame what they wanted to say in their mother-tongue or Tetum as widely use language communication in the Capital of Dili and then translated it into English, which often produces in mistakes. This type of condition, the learners used to local language pattern drives lose motivation in learn the target language and maximum practice of speaking skill.

The outside factors of less development country there are still lack of tied competitions in the areas of professional selective for certain jobs in Timor Leste.

Dominant of Language Use

The third semester students of English Department are often communicating in their Tetum and mother-tongue which resulted of losing motivation in learning English and lack of practice after wards

\subsubsection{Less of Practicing.}

The data sources stated through a direct interviewed that they have less of practicing their speaking skills with friends in class or after class. As soon as the class meeting terminated no more English words expressions of students could not be listened among the students but suddenly spreader in Tetum. This type of condition also affected of a mastery English speaking development in language learning atmosphere.

They did not speak a lot with friends on any different topics and they did not speak to themselves. The third semester students less timing on independent practice, without training talk in mind/brain. Less reading English text summarized what they have read, what they have listened to or watched of broadcasts.

Minimum transfer of personal's experienced into English conversation topic with friends or to him or herself. 
The less development of vocabs and experiences of knowledge that had shared by English speaking subject's lecture the students cannot apply speaking skills both in class and out of the class.

Time allocation.

The three credits time meeting with a forty five minutes per week for speaking class as the same as with two credits hours of forty five minutes or one and half hour meeting.

\subsubsection{Self Confidence of Poor Verbal Communication}

Through oral communication is always involving a very powerful of written communication system, which sometimes contradicted with the messages provided through the verbal communication that students got from listening channel. Lack of knowledge of the non-verbal communication system of the target language resulted in the powerlessness to pick up nonverbal signals by the English Foreign language students of such academic that produced in miscommunication aspect.

\subsubsection{Get Difficult to Memorize and Comprehension English Context Meaning.}

As the human consequently capacity of memorizing vocabularies of the third semester students are considered as main internal factor which is impeding their speaking skills development. The second case one is that personal's confidence, A continuous practice and patience are necessary to learn English Language to be used. The third semester students believed that it was not possible to achieve fluency or master such language due to a complexity meaning in certain expression. This such lack of confidence prevents them from learning the speaking skill.

\subsubsection{Less Enthusiasm in Listening and Learning}

The students less enthusiasm in learning and listening from the native speakers in the process of single way communication through audio, video and films on the language teaching of education program. The students are weak in imitating native English speakers' pronunciation in the process of learning English. While other colleagues with quick learners become inconvenient psychology which as affected pressure. There is no personal effort strategy to find best solution to overcome the difficulties that some of the third semester students faced.

\subsection{Findings Non-Linguistics Factors}

The non-linguistics factors which were impeding third semester students class A of English department program of Universidade de Dili-TL in the academic year 2017 were the direct facilities and non-facilities use as the support part aspects in learning English for speaking skills. These factors can be seen in four point two point one to five as following.

\subsubsection{The Non-linguistics Features}

The second challenge external Factors which hampering third semester students in mastery English speaking skill view from support facilities such as books sources, library, language laboratory, students' centre and personal's lap tops. Social environment, cultural aspect and improperly guidance.

\subsubsection{Lack of Facilities}

The facilities as described in the research findings mostly regarding to books on English language teaching, methodology of teaching and learning are very limited. Rooms, rooms here indicating about spaces of places where used for teaching and learning activities where handled conditions not support because the size of classroom only 4 by 6 metres available two rooms and two rooms with size of 7 by 7 metres. The rooms just equipped with one works fun, therefore uncomfortable warm aspect students in few minutes meeting. These support facilities included language laboratory and its supports accessories, students' centre for practice and extracurricular activities. The another support Library that provides source books it only has six to eight reading tables.

\subsubsection{Lack of English book sources}

The twenty four of third semester students stated that they would like to improve their English in general and speaking skills in particularly at such of English Department as the higher expectations but the reality is in a different condition. The different here concerning about the English book sources which are relevant to learning English for education program studies on English language teaching are not available. The just has English general books and without English language teaching books. The library was inspected by international experts on education program found that the education's three shelves only have one book on English language teaching on a reference shelf. 
It was found that the only two or three English books on English language teaching available.

The students have less English books to improve their English competences and skills. They are expected from the English department and the university but the two academic bodies could not supply enough development science equipment. The students only got inputs from the teachers' hand-outs for equipped them. For a youth nation Timor Leste which is facing with complexities problems of varieties' less development students just relay on human resources such professional teachers of the English Department study program but it only has four permanent lectures. This number of facilitator is far from an English study program of a university. The English Department has not provided the four language components and skills books that can help the students.

English Department Program Study without language laboratory and its equipment that could support the students' enthusiasm learning. The English department had set up rules and regulation to reach its institution objective to produce future qualitative professional output but the institution without language laboratory as above mentioned.

\subsection{Library and Its Equipment}

The university's library is also doesn't have up to date relevant English books on education program teaching methodologies for the receptive and productive skills in general and the specification speaking skill competences through English spoken and the written process.

The university only has5 to 10 reading desks for facilitating all six faculties's students and lectures those who access the library. Means that such library does not have space enough to accommodate reader numbers above 50s students at a single hour.

\subsubsection{Without Students' Centre}

The department does not equip the learners with supportive facilities of rooms, sound system, conditions and other accessories for extracurricular activities room for practicing.

Due to insufficient space facility at campus English students cannot enhance their speaking skill in a proper preparation condition that would set up new or experience moment.

Extra-curricular hours

There was no extra time allocation for specific speaking practice group's preparation as development strategy at campus. The chance meeting hours between students with English teacher and among students at campus were just for class meeting hours only. The three credits time meeting with a forty five minutes per week for speaking class as the same as with two credits hours of forty five minutes or one and half hour meeting. Viewed to the regards condition, the writer would say that third semester students could not get optimum result.

\subsubsection{Social Factors, at Home and Campus}

The outside factor such social Some of the third semester class A of English department in the academic year 2017 stated that they never speak English at home due to none of family members speak English as a support aspect of leaning English as foreign language. One of the informant stated that even her brother is a English teacher at senior high school but they did not further debate any certain topics in English.

When the students have backed home their English study as the last option after family daily works handled. The solution of the challenges faced by the third semester students will be serious attention of the Dili University and the English program study program have to review the curriculum and time allocation meeting or specific duties on encouraging English learning processes.

The second social factors at campus, the students' daily communication at campus with through Tetum is more dominant, and they only use English when facilitators communicate with them in class some just quite. But when the class meeting session with lectures was end the atmosphere of communication broadly shifted into Tetum immediately. This type of communication as one contributed discourage some English learners of English department study program of self- learning and find out solution. The students also confirmed some English teachers used Tetum for tutoring students in class. 


\subsubsection{The Economy Factor}

Some of the third semester students stated that in consequence family economic back ground of minimum income they could not have enough finance support to buy source books and laptop to be used as support facilitate and equip them in developing their English skills. Other students stated that families not allowed them to have laptop and android mobiles to access internet.

\subsubsection{Lack of Properly Guide and Cultural Aspect}

All though some students have learnt English at their levels of junior and senior high school or course, they were still weak to produce even a good speaking skill performance in front of class, researcher and his companions lectures. The teaching speaking subject lecture lay more on good productive skill with excellent from students only. When students made mistakes then they have to get prejudiced remarks.

Insufficient Teaching Facilities of English Department.

There weren't of the lecture's proper teaching aids and facilities which cover

the proper space, books and teaching aids that created improper learning character for the third semester learners. In this case, the learners have got proper learning facilities and environment appropriateness, the third semester students learning process must be effective, efficiency and progressively.

Less Utilizing different methods of teaching is essential for the English speaking lectures to adopt different methods of teaching to attach the diverse needs of the students. There are numbers methods for teaching speaking skill, suchaudio-lingual method, translation method, direct method, cooperative learning, description and etc. The English speaking skill teaching methods should accordance with the diverse needs, techniques and styles of the speaking learners. Since the selection must be an attractive and interesting method would keep the student participated, motivated order to be used in their daily real-life circumstance.

\section{Cultural aspect:-}

In certain condition in which where the English learners were not practice their speaking skills among English learners members while they were shared a chance with their relatives who are not part of the English learner can be miss interpreted, because they worried that when they applying the English language it would break their relation in their society.

They were shy if their performance would be misleading or drive friends mind of ego with English and non-cultural act. Worried about miscommunicate with the interlocutor's perception that hide confidential matter to would break friends and relatives relation in the future. When train self-improvement speak English and it be considered that the speaker be crazy and afraid of other perspective which has linked with socio-culture.

The other circumstances are the traditional living systems in the transition process into globalism situation is still considered non-traditional culture ethic of the learners perspective.

There was not basic discourse language teaching skills applying in the process of teaching English speaking skills. This conclusion was taken based on data source interviewed that speaking teacher was dominated class and students have in the receptive action.

Inhabitant use English,

There was inhabitant of using language at target learning language of English. The common language used was hard for third semester students of English Department of UNDIL to scape. Mother-Tongue and Tetum were more used by the students in the class and outside of the class. Third semester students were generally tend to speak which were dominant use of their mother-tongue and Tetum when have chance enter to the activities in productive skill of speaking.

Poor Building Confidence

The external factors which are hampering mastering speaking skill for the third semester students can be seen as shown below: 


\section{Poor Building confidence:-}

The another important aspect wasn't build confidence in the learners expectations. The speaking skill lecture and department without adequate speaking source books for referential reading establishment a good try out with the learners' preparation step as an important aspect in build their confidence. This condition was deduct the process of starting and developing with encourage to carry out easy tasks by the students. The second one was discouraged the slow learners to participate in the activity and enhancement in their morale. The students' confirmed that there were minimizing students' talks time and maximizing lecturer's talk time which also discouraged the learners. The less permanent lectures of English department is also a direct impacting in mentor, guide in the process of save students out of the inhabitation learning English.

Social Background

The conditions of third semesters' environment in which they are living with variant of community member's character that also affect condition of learning. Regarding socio-culture influence and family background where they also play a vital role in the learning process. Some of the six students stated that stay with family's relatives and religion covenants' dormitory have the limited hours for study.

The back ground of the third semester students of English Department in Timor Leste majority of them are peasants from rural areas and lower educational background. The English teacher's profession learners coming from such background when asked to take part or do a speaking activity they fail to do it. In relation to this information the writer would like to drawn an assumption that students still dominated in the shy mentality.

\subsubsection{Students capability}

There were students' capabilities in speaking performance and their inner factors which were insufficient facilities and conditions.

Data sources observation of speaking performance evaluation through reading text and speaking skills of a short text between five to fifteen lines as the steps to find out the hampering factors in the personal interview.

Less of vocabulary. Not dominate the text, the students did not dominate the some vocabulary of the text therefore then just they presented what was the title they read and followed by closing her/his speaking.

Shy factor, for a miss-pronunciation, the ideas of the text read with low voice. The ideas for a development through their own perceptions were limitedly or chased away. The minimum ability on totally or partial knowledge for a text drove out them to a relevant situation that unpredictable by students.

Shy to speak in front of more people, 10 students out of 24 indicated fear feeling was dominated and won't speak more and develop what was text shared. When they had finished read text without share any ideas text content to other participants but immediately terminated his/ her speaking session.

\section{Structure}

The students' composition of writing process and speaking are sometimes interfering with Tetum and vernacular structures. They also worried that some the sentence arrangement ignoring grammar rules.

Incapable Developing ideas with the text given

The six of the 24 four students tried out to speak around the topics given even they were not dominate the whole text. And the rest just re-read the text bravely with wrong pronunciation in front of other presenters and terminated his or her presentation said that's all thank you.

Less practice with colleagues being laughed after words. Due to experience problem, the students cannot distinguished a taxi that can landing and departure form a certain vacant places such on soccer field, snow area, sands and etc. This taxy was a small air craft that used pick up and drop people to and from unavailable airport as normal aero planes do.

Second external factors that challenge their English speaking skills found through a direct interviewed after presentation concluded. Lack facilities such source books, language lab, outside campus daily communication in Tetum.

Pronunciation - While presenter read text more interference in the way of how to read Tetum and Bahasa Speaking development - average and personnel. 
Shy - when writer observed to terminate their speaking skill through reading text served that they were reading and speaking with low voice short sentences. Speaking read, immediately verbal interview -

Structure errors detected source's responding question through writing process for describing what is the internal and external factors that challenging each source.

Desire character is as philosophy aspect to acquire non- native language in the process of language acquisition of a foreign language as effective and efficient as possible is the one common aim of the numerous theories and approaches of language teaching. The only a specific approached to English learners of third semester students as the key approach of teaching English speaking skill has to task-based approach. By a touch atmosphere wherein the learners of third semester students have to actively engage in the process of acquiring the speaking skill in order to achieve a goal or a complete given task. Tasks can easily be related to learner's real-life language. They create contexts that facilitate second/foreign language acquisition and focus on form. Learners are more likely to develop intrinsic motivation in a task-based approach. This enables the teacher to see the progress in the learner's ability to communicate in English.

To facilitate the process of enabling learning foreign language speaking skill or a major subject can be effective when both the leaner and the tutor are involved in the process and derive pleasurable out of the subject. Through the only way to maintain the students' motivation and interest levels in a higher stage. When this procedure is achieved all the problems of teaching and learning get resolved and better results are attained.

\section{Chapter v}

Conclusion and suggestion:-

Through this chapter the writer would like to express the phenomenal conclusions and suggestions regarding to this research. This proper study is focus on factors hampering third semester students' mastery English speaking skill of English Department of Universidade de Dili in the academic year 2017. The objection of the main study is to identify the internal factors and external factors which are challenging students' speaking skill progress. The influence such Language features, psychology, non-language, facilities, Sociology and economy factor.

\section{Conclusion:-}

In fact that all the students have learnt English during three semesters had a mutual cooperation with speaking skill's lecturer. The observation data analysis indicated that developing students' performance stimulation administratively executed through a lecture's methods, techniques, personal approaches, lesson plan and other supports handouts. The students also had learnt about basic lessons of English structure, reading, writing and speaking skills as the basic equipment for the third semester students' progresses but the fact shows in other way. In connection to the students' effort learning but there are still have internal factors challenge of personal psychology, philosophies aspects and external factors of a non-development country that direct impact of development speaking skill such English text books, internet connection, transmits language as medium between English to Tetum and other sources.

Regarding a speaking skill development have tied relation between students' internal factors of enthusiasm in learning English to earn more vocabularies, dominate tenses, grammar use of word ascertain, brave to share ideas with other native speakers both direct and indirect dialogues in order to mastery the English speaking skill but did not them with optimal due to inner personal factors and extern factors. Students have to be good memory at all lessons learnt as personal best strategy to learn English.

In link with the above paragraph, the data showing that the third semester students are dominant influenced by the lack of vocabularies, shy for being mistakes, less practice, weak memory to keep lessons learnt.

Without fluency speaking of the third semester students caused by the following factors: lack of vocabularies, shy, miss-pronunciation, grammatical rules, less practice, low motivation of study and other aspects as mentioned in the internal cases the third students could not speak fluently in front of many people.

Another aspect is self confidence in a poor verbal communication which supported by the get difficult to memorize and understand of lessons learnt. 
In the process of communication students could not which words and phrases be part of past and present. Phrases and sentence of past directly expressed into present condition.

The external factors which were hampering mastering speaking skill for the third semester students can be seen as shown in the following aspects:

Lack of English Book Sources

The twenty four students of third semester stated that they would like to improve their English in general and speaking skills in particularly at such of English Department as the higher expectations but the reality is in a different condition. The different here concerning about the English book sources which are relevant to learning English for education program studies. The students have less English books to improve their English competences and skill. They are expecting from the English department and the university but the two academic bodies could not supply enough. The students only got inputs from the teachers' handouts for equipped them. For a youth nation Timor Leste which is facing with complexities problems of varieties' less development students just relay on human resources such professional teachers of the English Department study program but it only has four permanent lectures. This number of facilitator is far from an English study program of a university. The English Department have to provide the four language components and skills books that can help the students.

During the research time it was discovered that in the Universidade de Dili's library part of English education bookshelves only found two or three books on English language teaching. The writer was also not aware on that, but an international expert on education Prof. Dr. Faizah ABD. Majid, (MQA) from Malaysia for accreditation visits,observation, searching the book-shelves and found them then suggested add more.

English Department Program Study without language laboratory, book sources room spaces to facilitate students' speaking development.

The environments influence

The outside factors such social and environment contributed challenge. Some of the third semester class A of English department in the academic year 2017 stated that they never speak English at home due to none of family members speak English as a support aspect of leaning English as foreign language at home. The second social factors at campus, the students' daily communication at campus through Tetum language unavoidable was more dominant, and they only use English when facilitators communicated with them in class. In class when English facilitators communicate in English more dominant caused some of students just quiet without confirmation on nonunderstand topics as discussed with their lecturers. After class meeting end the class' communication atmosphere shifted immediately into Tetum. This kind of condition did not support third semester students' motivation in learning speaking skill and implementing improvement.

\section{The Used of Minimum Methods in Teaching Speaking Skill:-}

English speaking lecturersare not aware of the essential part of adapting different methods of teaching English speaking skill to attach the diverse needs of the students. There are numerous methods for teaching speaking skill like screening film, video, audio-lingual method, translation method, direct method, cooperative learning, and description.

\section{Factor of economy:-}

Some of the third semester students stated that they could not have enough finance support to buy source books and laptop to facilitate them. Other stated that families not allowed them to have laptop and mobiles to access internet. The grammatical rules between English and Tetum language or vernacular are quite different.

The most of the third semester students are from weak economic families of rural areas and staying with family's relatives.

Linguistics and non-linguistics features

In the research observation on English speaking skills through a reading text and presenting by each data source indicated that all of the third semesters students of class A they were facing different level of internal factors such weak at remembering lesson learnt, how to apply lesson learnt in a real situation. 
Pattern Mother-tongue, Tetum, Bahasa Portuguese

The four languages' patterns influence third semester students in relay on a particular set of pronunciation, intonation, stress-pattern and phonology.

They were shy if their performance would be misleading or drive friends mind of ego with English as non-cultural ethic act.

Language patterns influence

Third semester students were generally tend to speak which were dominant use of their mother-tongue and Tetum when have chance enter to the activities in productive skill of speaking. When the third semester students of class A were asked to perform a speaking practice they first chance immediately commence formulate about the text/topic in their mother tongue or Tetum, Bahasa, frame what they wanted to say in their mother-tongue or Tetum as wide language communication use in the Capital of Dili and then translate it into English, which often produces in mistakes. This type of condition the learners used to local language pattern drive to lose of a motive learn the target language and maximum practice.

The third semester students of English Department often tend to make use of their Tetum and mother-tongue which resulted in losing the motive of learning the English and lack of practice.

Lack of properly of guide and self-tried out

Speaking subject lecture lay more on good productive skill with excellent from students only. When students made mistakes then they have to get prejudiced remarks. Other aspect of improperly guide was caused by rarely speaking teaching methodology source books of the department and university.

An interesting aspect of this research found that third semester of class A more dominant by women students.

\section{Suggestion}

After conducting field research at the site as mentioned in the previous chapter three, the would like provides some suggestion regarding findings and the conclusion above mentioned, the researcher wants to give input for the English department students, speaking lectures and key person of English department program for an improvement process hand out duties.

Students have to try hard in certain ways of leaning in order to avoid inhabitation learning and both of practice verbal and non-verbal communications both at campus and outside while handling tasks. All students have to try out motivating themselves in learning strategies that could help improving, developing and evaluation of learning English.

The speaking lectures have to review all lesson learnt and methodologies to improve students' English speaking skill with an adequate relevant approach of language teaching techniques.

The department of English education study program has to coordinate with university to provide supportive facilities on English education program such English language teaching book sources, laboratory, and students' centre for practicing skills. The English department's key authorities have to invite experts to review English curriculum, semester's burden subjects and meeting hour allocating and deliveries tasks students concentrates.

The university has tied and continuously cooperation with UNDANA university in upgrading English lectures' teaching performance and English language teaching on newest methods.

The English program study has to review the curriculum objectives and the meeting hours with distribution subject per semester in order the students have the chance finalizing tasks and research sources books, audio, videos for self-confidence study in developing skills of speaking

Enrolment students' selection and three month intensive course training before enrolment test. 


\section{References:-}

1. Bire, Jos, (2016) Issues in Teaching English as a Foreign Language in Indonesia.

2. ............. (2014). The five types of Adverbs.

3. Boyer. Susan, 2014. Understanding a Spoken English a focus on Every Day language in Context. Boyer Educational Resources, International edition.

4. Brown, James Dean 2015. Teaching Connected Speech.

5. Burns, A and Joyce, H. (1997) Focus on Speaking. Sydney National Centre for English Language Teaching and Research.

6. Bruner, J. (1985). Models of the Learner, Educational Researcher, American Educational Researcher Association

7. Bygate, M. (1987). Speaking. Oxford: Oxford University Press.

8. .......... (1998). Theoretical Perspective Speaking on Speaking. Annual

9. Review of J. Applied Centre of Applied Linguistics. Oxford: Oxford University Press.

10. Caslon, W. (1728).A Specimen of typeset fonts and languages.

11. Celce- Murcia, M., Dorneyi, Z., and Thurrel, S. (1995). Communicative Competence: A Pedagogical Motivated Model With Content Specification. Issues in Applied Linguistics 6, 5-35.

12. Corbleet, S. and Carter, R. (2001) The Language of Speech and Writing.

13. London: Routledge.

14. Constitução da Republica (2002). Constitução da Republica de Democratica de Timor Leste. Dili: Parliament.

15. Denzin, N.K. and Lincoln, Y. S. (9184). Hand Book of Qualitative Research, Newbury Park: Sage Publication Finochiaro, M. (1974). English as Second Language: From the Theory to Practice. New York: Regent Publishing.

16. Etik, Yuliana 2013 the Use of Picture to improve Reading Skill. ....(Thesis)

17. Eric Digest. (Erick) Document Reproduction Service no. ED: 435204

18. Easy English (2009). Different types of adverbs. English grammar.com (2014).Types of Adverbs. Retrieved January 12, 2014, from Florez, M.A. (1999) Improving Adult English Language Learners' Speaking Skill.

19. Harmer, J. (1991).The Practice of English Teaching. London: Corner International, East Kilbride.

20. Horton, Paul B. and Leslie, Gerald R. (1955). The sociology of Social Problems. Michigan and Florida University

21. Kapitan, Alexander, 2016. The Implementation of speaking Skill Instruction.

22. Latief, Mohammad Adnan, 2012. Research Methods on language learning.

23. Universitas malang.

24. Labov. William, 1976. Sociolinguistics Patterns. Forth Eddition Univ. of Pensylvania Press, Philadelphia.

25. Mills. Robin, 1962. Speaking of values Conversation and Listening. Pearson Logman.

26. McNeill, R. (1986). English Language.

27. My English grammar.com (2014). Adverbs.

28. Richards J.C. \& Rodgers, T.S.(1986). Approaching and Methods in Language Teaching. London: Cambridge Language Teaching Library.

29. Richard, J. C. (2008). Teaching Listening and Speaking, From Theory to Practice.

30. Cambridge: Cambridge University Press.

31. Setiadi, Bambang Ab, 2006. Metodology Penelitian Untuk pengajaran Bahasa Asing.

32. Grhaha Ilmu.

33. Sudaryanto, 2016, Metode dan Aneka Teknik Menulis Bahasa. Universitas Sanata Dharma Anggota APPTI.

34. Sudaryanto, 2o16, Cerdas Menulis Karya Ilmiah. Sanata Dharma Universitas Anggota APPTI

35. ..........., Discipline in the secondary classroom. B Jossey-Bass Teacher Tagrat, G. L. Wilson, A. P. 2005. Promoting in reflective Thinking in Teachers. California: Corwin- Press, B. Madhavi, Latha and Celta, 2012. Teaching English as A Second Language: Factors Affecting Learning Speaking Skills

36. The capital community college Foundation (2014).Adverbs. The Free Dictionary (2013). English Grammar Checker.

37. Vol. 1 Issue 7, September - 2012, Teaching English as A Second Language: Factors

38. Affecting Learning Speaking Skills

39. Whitlam, G. (1999). The Australian Oxford Dictionary. Melbourne: Oxford University Press.

40. Yates, J. (2006). Master the Basic English Course. New York: George Washington University. 
Retrieved on January 15, 2014 from

http://esl.about.com/cs/intermediate/f/f_adverbs.htm

Retrieved

January 2, 2013, from http://en.wikipedia.org/wiki/Language

Retrieved January 12, 2014, from http://www.beidaenglish.com/easy-english/different-types-of-adverbs/ http://www.myenglishgrammar.com/lesson-4-adverbs/3 forming-adverbs.html

Retrieved on January 15, 2014 from

http://esl.about.com/cs/intermediate/f/f_adverbs.htm

Retrieved January 12, 2014, from http://grammar.ccc.commnet.edu/grammar/adverbs.htm

Retrieved on December

23, 2013, from http://www.thefreedictionary.com/text

Retrieved January 12, 2014, from

http://grammar.about.com/od/ab/g/adverbfunction.htm

Retrieved December 10, 2013, from

http://www.answers.com/topic/english-language

Retrieved on December

23, 2013, from http://www.thefreedictionary.com/text

Retrieved January

12, 2014, from http://grammar.ccc.commnet.edu/grammar/adverbs.htm 